
$\$$ Research Square
Preprints are preliminary reports that have not undergone peer review.
They should not be considered conclusive, used to inform clinical practice, or referenced by the media as validated information.

\title{
Ethnoveterinary medicine practices of Guji Semi- Pastoralist People, Suro Barguda District, West Guji Zone, Oromia Regional State, Ethiopia
}

Mersha Eshete Ashagre ( $\triangle$ mae19590917@gmail.com )

Addis Ababa University https://orcid.org/0000-0001-6133-8521

Ermias Lulekal Molla

Addis Ababa University Faculty of Science: Addis Ababa University College of Natural Sciences

\section{Research}

Keywords: Indigenous knowledge, Livestock ailments, Medicinal plants, Suro Barguda District

Posted Date: March 30th, 2021

DOl: https://doi.org/10.21203/rs.3.rs-340502/v1

License: (c) (1) This work is licensed under a Creative Commons Attribution 4.0 International License.

Read Full License 


\section{Abstract}

Background: This research aimed to identify and document ethnoveterinary medicinal plants and their associated indigenous knowledge, their preparation, application methods used by traditional healers, and status of their conservation with Guji Semi-Pastoralist People of Suro Barguda District, West Guji Zone, Oromia Regional State, Ethiopia.

Methods: Ethnoveterinary medicinal plants data were collected by interviewing 196 informants (145 males and 51 females). Guided field walks and discussions (group and individual discussion) were used in collecting the data. Quantitative approaches were used to determine the informant consensus factor (ICF), fidelity level (FL), and use value (UV). Ethnoveterinary medicinal knowledge apprehended by different informant categories was compared using t-tests with R-software.

Results: Forty-six ethnoveterinary medicinal plant species representing 43 genera and 29 families were identified in the district (Appendix 1). About 26.1\% of the families (twelve families) were represented by more than one species. The highest number of species was recorded for Asteraceae ( 5 species, $10.9 \%$ ), followed by Euphorbiaceae (4 species, $8.7 \%$ ) and most ethnoveterinary medicines were prepared from herbs and shrubs than other growth forms. Chopping/pounding the remedial parts and homogenizing them with cold water was found to be the major mode of remedy preparation. All the documented ethnoveterinary plant species were harvested from the wild and observed as exposed for depletion. About $4.4 \%$ (two species) of the ethnoveterinary medicinal plants of Suro Barguda District were endemic to Ethiopia.

Conclusion: This study indicated that the study area encompasses different species of ethnoveterinary medicinal plants which should be given conservation priority and the local community depends largely on these plants for the treatment of different livestock ailments though the healers had a very high intention to keep their traditional knowledge secrete. The indigenous knowledge of pastoralists about plants (a traditional system of rangeland management) and livestock (breeding different species of livestock (grazers with browsers), as well as their environmental management system (traditional forest, soil, and water conservation system), should be incorporated in the planning and implementation of developmental interventions.

\section{Background}

Ethiopia has the highest number of livestock in Africa and the country is listed among the top 10 countries in the continent known for their livestock wealth [1]. Livestock is an integral part of agriculture, accounting for about 45 percent of the total value of agricultural production and supporting the livelihoods of a large share of the population. The national herd comprises 57 million cattle, 30 million sheep and 23 million goats, and 57 million chickens, as well as camels, equines, and a small number of pigs. Due to technical, economic, and institutional constraints, livestock productivity is generally low. Beyond providing foods and other goods and services to the population, the livestock sector is a major 
contributor to export earnings, mainly through the export of live cattle and small ruminants. It is estimated that Ethiopian livestock contributes about 10 percent to total export earnings, of which 69 percent accounted for by live animal exports [1]. Despite this large number of livestock and its important economic potential, still, the sector has not developed beyond a subsistence type of undertaking, whereas it also remained with low outputs for different reasons of which animal diseases are among the top factors [2]. Animal health could be managed traditionally through ethnoveterinary medicine practices which are a mode of identifying, use, and integration of the local knowledge, related skills, and customs procedures created by people for purpose of preserving the health and welfare of working and productive animals [3].

The ethnoveterinary systems are an ecological unit and ethnic community-specific and therefore, the characteristics, sophistication, and intensity of these practices differ greatly among individuals, societies, and regions. However, they are facing the threat of rapid erosion because of rapid socio-economic, environmental, and technological changes [4]. Even though indigenous knowledge systems are rapidly disappearing under the influence of Western culture, $80 \%$ of the world's populations exclusively rely on traditional medicine [5]. More than $80 \%$ of the human population and $90 \%$ of the livestock depend on traditional medicine in Ethiopia [6, 7]. The persistence of ethnoveterinary healthcare in Ethiopia is related to the high cost of treatment using modern veterinary drugs and the prohibitive distance of the veterinary stations from the rural areas [8]. Elderly community members with this knowledge were dying and the introduction of modern practices made it difficult for the younger generations to appreciate and use the beliefs and practices of their ancestors [9], and it has not yet been well documented, promoted, conserved and much effort is needed in research and integration activities in the country. There is a wide gap in our knowledge about ethnoveterinary data and information from various parts of Ethiopia although we have rich and diverse ethnolinguistic groups throughout the country. Ethnoveterinary medicine is communitybased local or indigenous knowledge and methods of caring for, healing, and managing livestock. It is treating of four times: the man, the animals, the plants and the soil, old African saying [9]. Ethnoveterinary medicine is a scientific term for traditional animal health care that encompasses the knowledge, skills, methods, practices, and beliefs about animal health care found among community members [10]. This knowledge is based on close observation of animals or the oral transmission of experience from one generation to the next [11]. This rich repository of local knowledge about almost all aspects of livestock care is inherent in most of the rural and tribal communities and pastorals. Ethnoveterinary medicine could be a key veterinary resource and could add useful new drugs to the pharmacopeia, and it can contribute to biodiversity conservation [12]. Ethnoveterinary medicine is more environmentally friendly and often more socio-culturally acceptable and very suitable for use on smallholdings by livestock keepers who can prepare the traditional remedies themselves [10]. The extent of knowledge and utilization of ethnoveterinary medicine differ according to the culture and prevailing socio-economic characteristics [13]. Many indigenous veterinary beliefs and practices continue to function in a wide majority of livestock raisers, particularly in developing countries [14]. Ethnoveterinary practices have been developed by trial and error and by actual experimentation [15]. Ethnoveterinary medicine comprises traditional surgical techniques, traditional immunization, magico-religious practices, and the use of herbal medicines to treat 
livestock diseases $[16,17,18]$. Ethnoveterinary medicine provides traditional medicines, which are locally available and usually cheaper than standard treatments. Livestock holders can prepare and use homemade remedies at minimum expense. The knowledge of ethnomedicinal plants is on the edge of irreversible loss and declining to deterioration due to the oral passage of herbal heritage from generation to generation rather than in writings, despite their vital role in providing for the health of the human, and livestock population [19]. Environmental degradation, agricultural expansions, cultivation of marginal lands, and urbanization are also posing a significant threat to the future wellbeing of human and animal populations that have relied on these resources to combat various ailments for generations $[20,21,22]$ deserving urgent need to document and preserve the indigenous knowledge. So, this research was targeted to glean out information on how these practices were implemented in Guji semi-pastoralist people, Suro Barguda District, west Guji Zone, Oromia Regional State, Ethiopia.

\section{Materials And Methods}

\section{Description of the study area}

The present study was conducted in Suro Barguda District, West Guji Zone of Oromia Regional State, Southern Ethiopia. Suro Barguda District is established recently and located $497 \mathrm{~km}$ south of Addis Ababa - the capital of Ethiopia, and $30 \mathrm{~km}$ from Bule Hora town, the capital of West Guji Zone. The district is generally characterized by rough and rugged topography and lies between latitudes $5^{\circ} 30^{\prime} 0^{\prime \prime} \mathrm{N}$ and $5^{\circ} 50^{\prime} 0^{\prime \prime} \mathrm{N}$, and longitudes $37^{\circ} 50^{\prime} 0^{\prime \prime} \mathrm{E}$ and $38^{\circ} 20^{\prime} \mathrm{O}^{\prime \prime} \mathrm{E}$. The altitude ranges from 900 to $2350 \mathrm{~m}$.a.s.l. Suro Barguda District's Land Administration Office reported (unpublished annual report) that the total area of the district is 154,958.4 hectares (Figure 1).

This district is divided into two agro-ecological zones, namely the lowlands (from 900 -1500 m a.s.l) and the middle altitude ranging from 1501-2500 $\mathrm{m}$ a.s.l. Accordingly, the proportion of the two agro-climatic zones in the district is $41.8 \%$ lowlands and $58.2 \%$ mid-altitude. The district falls within the southern bimodal rainfall regime of Ethiopia $[23,24]$ and is justified by Figure 2. Since there was no Meteorological Station at Suro Barguda District, fifteen years of Meteorological data $(2004-2018)$ registered by the nearby Station (Bule Hora District Station) was taken from National Meteorological Service Agency. Based on the analysis of this data the district receives high rainfall between March and half of June as well as a relatively good amount from half of September to half of December. The dry season extends from half of December to February and some extent from half of June to half of September. The highest mean annual average rainfall of the study area within fifteen years was $171.3 \mathrm{~mm}$ recorded in May, whereas the lowest mean average was $12.4 \mathrm{~mm}$ recorded in February. The lowest mean average temperature over fifteen years was 10.8 Co recorded in December whereas the highest was 28.7 Co recorded in February. The mean annual rainfall of the study area was $853 \mathrm{~mm}$ whereas the mean annual temperature was 19.8 Co. Based on [25] classification of Ethiopian vegetation the study area vegetation is included in Acacia - Commiphora woodland and Bushland, Combretum-Terminalia Woodland, and Dry Evergreen Afro-Montane Forest and Grassland complex. 


\section{Demographics and livestock health care system in the district}

Since Suro Barguda District was established recently, a population census was not carried out. But the district is predominantly $(99.9 \%)$ occupied by Guji Oromo people who speak the Oromo language with unique dialect and the majority of the residents live in rural areas. Pastoralism with subsistence farming is the most common economic mainstay of the people. In one or another way, their livelihoods depend upon the presence of different plant species and vegetation. Modern veterinary services have been playing a relatively good role in the control and action taken to prevent livestock diseases in the past three decades in Ethiopia. However, they could not so far deliver complete coverage in preventive and healing health care practices because of inadequate veterinary health professionals, logistic problems, the unpredictable supply of drugs, and the high cost of drugs and equipment. Besides, the majority of livestock breeders in rural areas are far from the site of veterinary clinics/posts, and those who have access to these clinics may not be able to afford to pay for them [8]. Ethnoveterinary medicine provides traditional remedies, which are available nearby and usually cheaper than standard treatments. Livestock holders can prepare and use homemade remedies at minimum expense. For many livestock holders in Suro Barguda District where there are relatively few veterinarians and shortages of other facilities, traditional medications were the only choice to treat different livestock ailments.

\section{Site and informant selection}

A reconnaissance survey of the study area was conducted from May $06-21,2019$ to obtain information about the agro-ecology of the area, status of the vegetation, indigenous knowledge of the local people in using plants for different purposes and determine the sites from where and how the data should be collected. The study district had 10 semi-pastoralist kebeles (the smallest administrative units) and currently, these kebeles are rearranged/subdivided to be 19 kebeles to decentralize the administration processes. Study sites from the ten kebeles were selected based on distance from the administrative town (Suro town), and presence/absence of health facilities for collecting medicinal plant information.

\section{Informant size determination}

The informant size for collecting quantitative and qualitative data for medicinal plants research to ensure the required representative size of households from all semi-pastoralist kebeles was followed Cochran's (1977) formula as indicated by [26]. Informants were included from different age and sex groups of households of the 10 semi-pastoralist kebeles in the district.

$$
\mathbf{n}=\frac{\mathrm{N}}{1+\mathrm{N}(\mathrm{e})=}
$$


Where,

$\mathrm{n}=$ sample size for the research; $\mathrm{N}=$ total number of households in all the 10 kebeles.

$\mathrm{e}=$ maximum variability or margin of error $5 \%(.05) ; 1=$ the probability of the event occurring.

The total number of households in the 10 pastoralists' kebeles of the district was 386 . Hence, the informant sample size comes to;

$$
\begin{aligned}
& =386=386=196 \text { informants } \\
& 1+386(0.05) 2 \quad 1.965
\end{aligned}
$$

Therefore, the required informants (respondents) size was 196. Informants' size for each kebele was calculated using the amount of the number of households in each kebele to the total number of households of the 10 kebeles i. e.

Informants from each kebele $=$ Number of households of the kebele $X$ Total number of informants $/$ Total number of households.

For example, the informant size of Welena Bokosa kebele with a total household of 39 was 20, i.e. (39x $196 / 386=20$ ). The same calculation was used for the other study kebeles and two to four key informants were taken purposefully from each kebele based on the size of the households (a total of 24 key informants) including healers, herbalists, elders, and practitioners based on their knowledge as recommended by the local people. The purposive sampling technique is most effective when one wants to study a certain cultural domain with experts within the native people. The remaining 172 general informants (respondents) were taken by random sampling method to make sure that important informants categories from different age groups and sex are included (Table 1).

Table 1. Number of households and informants included for the ethno botanical data collection 


\begin{tabular}{|c|c|c|c|c|c|c|c|c|c|c|c|}
\hline \multirow[t]{2}{*}{ No. } & \multirow[t]{2}{*}{$\begin{array}{l}\text { Name of the } \\
\text { kebele }\end{array}$} & \multirow[t]{2}{*}{$\begin{array}{l}\text { Total number of } \\
\text { households }\end{array}$} & \multicolumn{3}{|c|}{$\begin{array}{l}\text { Key } \\
\text { informants }\end{array}$} & \multicolumn{3}{|c|}{$\begin{array}{l}\text { Randomly taken } \\
\text { informants }\end{array}$} & \multicolumn{3}{|c|}{ Total informants } \\
\hline & & & $M$ & $\mathrm{~F}$ & $\mathrm{~T}$ & $M$ & $\mathrm{~F}$ & $\mathrm{~T}$ & M & $\mathrm{F}$ & $\mathrm{T}$ \\
\hline 1 & $\begin{array}{l}\text { Denbela } \\
\text { Hara }\end{array}$ & 47 & 2 & 1 & 3 & 17 & 4 & 21 & 19 & 5 & 24 \\
\hline 2 & Didole Hara & 43 & 2 & 1 & 3 & 15 & 4 & 19 & 17 & 5 & 22 \\
\hline 3 & $\begin{array}{l}\text { Gelana } \\
\text { Meteri }\end{array}$ & 36 & 2 & 0 & 2 & 14 & 2 & 16 & 16 & 2 & 18 \\
\hline 4 & Hidha Korma & 37 & 2 & 0 & 2 & 15 & 2 & 17 & 17 & 2 & 19 \\
\hline 5 & Mediba & 40 & 2 & 1 & 3 & 14 & 3 & 17 & 16 & 4 & 20 \\
\hline 6 & Meteri & 31 & 2 & 0 & 2 & 13 & 1 & 14 & 15 & 1 & 16 \\
\hline 7 & $\begin{array}{l}\text { Motokoma } \\
\text { Hara }\end{array}$ & 39 & 2 & 0 & 2 & 16 & 2 & 18 & 18 & 2 & 20 \\
\hline 8 & $\begin{array}{l}\text { Sororo } \\
\text { Melka Jewe }\end{array}$ & 34 & 2 & 0 & 2 & 13 & 2 & 15 & 15 & 2 & 17 \\
\hline 9 & $\begin{array}{l}\text { Soyama } \\
\text { Suro }\end{array}$ & 40 & 2 & 1 & 3 & 15 & 2 & 17 & 17 & 3 & 20 \\
\hline \multirow[t]{2}{*}{10} & $\begin{array}{l}\text { Welena } \\
\text { Bokosa }\end{array}$ & 39 & 2 & 0 & 2 & 16 & 2 & 18 & 18 & 2 & 20 \\
\hline & Total & 386 & 20 & 4 & 24 & 148 & 24 & 172 & 168 & 28 & 196 \\
\hline
\end{tabular}

\section{Data collection}

Data collection was conducted two times; from July 01 to August 30, 2019, and November, 15 to December 30, 2019, and plants reported as ethnoveterinary medicine by the informants were collected. The data were collected following $[27,28,29]$. Semi-structured interviews, guided field walks, discussions, market surveys, and field observation, with randomly picked and key informants, were applied based on a checklist of questions. The selected informants in the sample site were interviewed using semi-structured interview which was translated into the local language (Oromo language) focusing on ethnoveterinary medicinal plants: their uses and management; from where they collect them; how could they manage if these plants cause negative side effect on livestock; which plant was more preferable in its use; how they know their habitat and time of availability; whether they obtained any economic benefit from ethnoveterinary medicinal plants or not; whether they had any tendency to cultivate some selected ethnoveterinary medicinal plants or not; about the level of any threat to the ethnoveterinary medicinal plants; what they suggest about the current conservation status of these plants; how widespread the medicinal plant/s in the area; whether there was disappeared medicinal plant or not; as there was any 
restriction or taboo in collecting medicinal plants or not; whether these plants had other purposes or not, etc.

A semi-structured interview questionnaire was an important tool for the collection of both qualitative and quantitative data at the same time. The informants participated in answering the questions by showing the plants that they used as a medicine during the guided field walk interview. An explanatory individual and group discussion were made with the informants at each locality and site focusing on the status of the vegetation and acceptance of ethnoveterinary medicinal plants by the community. Detailed Notes on facts and information about the respondents, history of medicinal plant users, history of medicinal plants, and other essential information (based on the questionnaire) were taken on site. During the discussion, the informants were free to explain about medicinal plants and their knowledge without being interfered with and restricted.

\section{Data analysis}

Ethnobotanical data were analyzed following the basic analytical tools [29, 30, 31]. Potentially effective medicinal plants were identified by the method of informant consensus factor (Trotter and Logan 1996) in [32]. So, rank-ordering (Preference ranking) of medicinal plants was used to determine their order of cultural importance across a community. The most important in the set was given the highest number, decreasing in number as the members of the set decreases in importance. Preference ranking was computed by taking 10 key informants to assess the degree of effectiveness on those medicinal plants highly cited by the informants used to treat a particular disease [29]. Direct matrix ranking is a more multifaceted version of preference ranking. Here informants order ethnoveterinary medicinal plants by considering several attributes one at a time, i.e. it draws explicitly upon multiple dimensions. Direct matrix ranking was performed as a group exercise in which participants reach a consensus on the ranking of each item based on their evaluations [29]. The ranking of threats on 10 ethnoveterinary medicinal plants that were reported by most of the informants in the study area was conducted using ten key informants as described by [29] and [33]. This information was used to determine the highest threats to traditional ethnoveterinary medicinal plants in the study area and help to suggest appropriate conservation measures as considered. Informant consensus factor (ICF) was considered for each group of ailments to identify the agreement of the informants on the reported cures for the group of aliments of the plant. ICF was computed as follows: several use citations in each group (nur) minus the number of species used (nt), divided by the number of use citations in each group minus one [3]. The mentioned ailments were grouped and then the ICF values were calculated as:

$$
I C F=\frac{n_{u r}-n_{t}}{n_{u r}-1}
$$

Ethnoveterinary medicinal plants that were effective in treating groups of ailments had a higher informant consensus factor value. 
The Fidelity level (FL) computes the significance of a species for a given purpose. Most commonly used medicinal plants have high fidelity level value. The fidelity level (FL) among medicinal plants of the study area was computed based on the following formula: $\mathrm{FL}=\mathrm{Np} / \mathrm{N}$. To calculate the percentage of Fidelity level: $\mathrm{FL} \%=(\mathrm{Np} / \mathrm{N}) \times 100$ was used [33]. $\mathrm{Np}$ is the number of informants who independently cited the importance of a species to treat a particular disease, and $\mathrm{N}$ is a total number of informants who reported the plant to treat any given disease.

The local importance of each species cited in the study area was calculated using Use-Value (UV) technique following [11]. Use-Value (UV) is a quantitative method that demonstrates the relative importance of species known locally, which reflects the importance of each species to informants i. e.

$U V_{\text {is }}=\Sigma U_{\text {is }} / n_{\text {is }}$

Where $\mathrm{UV}_{\text {is }}=$ use value of a species s for informant $\mathbf{i}$,

$U_{\text {is }}=$ the number of uses mentioned in each event by informant $\mathbf{i}$, and

$n_{\text {is }}=$ the number of events for species s with informant I

\section{Results}

\section{Medicinal plant diversity used for ethno veterinary medication in Suro Barguda District}

A total of 46 ethnoveterinary medicinal plant species representing 43 genera and 29 families were identified in the district (Appendix 1). About 26.1\% of the families (twelve families) were represented by more than one species. The highest number of species was recorded for Asteraceae ( 5 species, $10.9 \%$ ), followed by Euphorbiaceae (4 species, $8.7 \%$ ) and Apiaceae, Rubiaceae, Rutaceae, and Solanaceae with three species (6.5\%) each. About 4.4\% (two species) of the ethnoveterinary medicinal plants of Suro Barguda District were endemic to Ethiopia. Concerning the growth forms of plants used for livestock treatment, there were more herbs and shrubs (12 species, $26.1 \%$ each), followed by trees (10 species, $21.7 \%$ ) and lianas (6 species, $13 \%$ ). All the documented ethnoveterinary plant species were harvested from the wild and overgrazing, deforestation; charcoal making, and firewood collection were claimed as major factors affecting the ethnoveterinary plant species of the study area.

\section{Livestock ailments and their prevalence}

A total of 79 veterinary ailment types were identified in the study area for which informants reported to use one or more medicinal plant species (Appendix 1). Of which twenty-six (32.9\%) veterinary ailment types belonged to breathing system diseases, sixteen (20.3\%) were gastrointestinal diseases and twelve (15.2\%) diseases belong to blackleg, hepatitis, and FMD (Foot and mouth) disease categories. Diarrhea and breathing problems were found to be the most commonly reported (most prevalent) types of livestock ailments in the district. 


\section{Applications of ethno veterinary remedies}

Even if ethnoveterinary medicinal plants of the district were asserted to be applied for ailments affecting chicken, sheep/goats, cattle, equines, or camels, the majority of the reported medicinal plant species (40, $87 \%$ ) were found to be applied to treat one or more of the sixty-two different cattle ailments (Appendix 1). Eighteen (39\%) equal medicinal plant species were mentioned to be used specifically against twenty-one ailments of goats/sheep and nineteen ailments of equines respectively (Figure 3).

\section{Medicinal plant parts used for ethnoveterinary remedy preparation}

Regardless of the different plant parts reported to be used for remedy preparation by the community, a greater proportion (41.9\%) of the preparations was found to be from leaves alone, followed by barks and roots $(12.8 \%$ ) each (Figure 4). Plants in mixtures of leaves rated to $10.5 \%$, latex $5.8 \%$, and stem $3.5 \%$ in the ethnoveterinary medication of the district. Most remedies $(98.8 \%)$ were prepared from freshly harvested plant parts.

\section{The approach of remedy preparation, routes of administration, and dosages}

Different modes of ethnoveterinary remedy preparation were reported to be used in the district based on the type and degree of complexity of livestock ailment. Chopping / pounding the remedial part and homogenizing it with cold water was found to be the major mode of remedy preparation $(93.1 \%)$ and unprocessed forms covered only $6.9 \%$ (Figure 5).

These ethnoveterinary remedies were reported to be given through oral, dermal, or nasal routes. The oral application was the most-cited route of administration (20 preparations, $66.7 \%$ ), followed by nasal (six preparations, $20 \%$ ), and dermal (four preparations, $13.3 \%$ ) routes. The physical appearance of the diseased animal and visually confirmed the degree of complexity of illness was used to determine the doses of the remedy prepared to treat livestock ailments. Some traditional practitioners reported the use of the coffee cup, water glasses, and bottles to determine dosage for some medicinal preparations, while others reported using a handful or full of a small dish unprocessed parts to treat ailments. However, no standardized doses of herbal preparations were reported by traditional practitioners for any of the remedies used to treat livestock ailments in Suro Barguda District.

\section{Most preferred ethno veterinary plants}

A preference ranking exercise with 10 key informants for eight medicinal plants that were reported to be used against breathing system diseases showed that Viscum congolense and Clematis simensis were the most preferred species to treat the reported diseases (Table 2). 
Table 2. Results of preference ranking exercise of eight medicinal plants reported for treating breathing system diseases of livestock

\begin{tabular}{|c|c|c|c|c|c|c|c|c|c|c|c|c|}
\hline \multirow{2}{*}{$\begin{array}{l}\text { Plant spp. treating breathing system } \\
\text { diseases of livestock }\end{array}$} & \multicolumn{10}{|c|}{ Informants designated $\mathrm{A}$ to $\mathrm{J}$} & \multirow{2}{*}{$\begin{array}{l}\text { Total } \\
\text { score }\end{array}$} & \multirow[t]{2}{*}{ Rank } \\
\hline & A & B & C & D & E & $\mathbf{F}$ & G & $\mathbf{H}$ & I & $J$ & & \\
\hline Ammocharis tinneana & 4 & 3 & 4 & 5 & 5 & 6 & 7 & 6 & 5 & 5 & 50 & $7^{\text {th }}$ \\
\hline Clematis simensis & 8 & 7 & 6 & 8 & 5 & 4 & 6 & 5 & 7 & 6 & 62 & $2^{\text {nd }}$ \\
\hline Heteromorpha arborescens & 7 & 6 & 8 & 5 & 4 & 6 & 5 & 3 & 6 & 7 & 57 & $5^{\text {th }}$ \\
\hline Lannea rivae & 8 & 6 & 5 & 7 & 6 & 4 & 6 & 7 & 5 & 6 & 60 & $3^{\text {rd }}$ \\
\hline Leucas abyssinica & 5 & 4 & 4 & 6 & 5 & 3 & 4 & 5 & 6 & 3 & 45 & $8^{\text {th }}$ \\
\hline Phytolacca dodecandra & 6 & 5 & 5 & 6 & 7 & 4 & 5 & 6 & 3 & 6 & 53 & $6^{\text {th }}$ \\
\hline Senecio hadiensis & 7 & 8 & 6 & 7 & 5 & 8 & 6 & 4 & 4 & 4 & 59 & $4^{\text {th }}$ \\
\hline Viscum congolense & 6 & 8 & 7 & 8 & 6 & 5 & 8 & 6 & 7 & 8 & 69 & $1^{\text {st }}$ \\
\hline
\end{tabular}

N.B. Scores in the table indicate ranks given to medicinal plants based on their efficacy (highest number (8) was given for the medicinal plant which informants thought most effective in treating breathing system diseases and the lowest number (3) was given for the least effective plant.

\section{Multipurpose medicinal plants used for livestock ailments and their conservation status}

The output of the average direct matrix ranking score of ten key informants for five medicinal plant species with six use diversities indicated that some multipurpose medicinal plant species were currently exploited more for firewood, charcoal, and construction purposes than for their medicinal uses (Table 3).

Table 3. Average direct matrix ranking score of ten key informants for five medicinal plant species with six use diversities 


\begin{tabular}{|lrrrrrrrrrr|}
\hline Medicinal plant species & \multicolumn{4}{c}{ Use categories } & & Total & Rank \\
\cline { 2 - 9 } & Ch & Co & Fr \&TI & Fw & Md & We & & \\
Combretum collinum & 5 & 2 & 2 & 5 & 3 & 0 & 17 & $3^{\text {rd }}$ \\
\hline Dichrostachys cinerea & 5 & 4 & 1 & 3 & 3 & 0 & 16 & $4^{\text {th }}$ \\
\hline Lannea rivae & 2 & 2 & 1 & 3 & 3 & 2 & 13 & $5^{\text {th }}$ \\
\hline Prunus africana & 4 & 5 & 4 & 5 & 5 & 0 & 23 & $1^{\text {st }}$ \\
\hline Syzygium guineense var. guineense & 3 & 5 & 3 & 5 & 3 & 3 & 22 & $2^{\text {nd }}$ \\
\hline Total & 19 & 18 & 11 & 21 & 17 & 5 & 91 & \\
\hline Rank & $2^{\text {nd }}$ & $3^{\text {rd }}$ & $5^{\text {th }}$ & $1^{\text {st }}$ & $4^{\text {th }}$ & $6^{\text {th }}$ & & \\
\hline
\end{tabular}

Where, $\mathrm{Ch}=$ Charcoal, $\mathrm{Co}=$ Construction, $\mathrm{Fr} \& \mathrm{TI}=$ Furniture and Tools, Fw $=$ Firewood,

Md $=$ Medicinal and We $=$ Wild edible

Informant consensus on most frequently used medicinal plants used for treating livestock ailments in the study area

This study clarified that some medicinal plants were well known in the study area than others. As a result, fifty informants cited such plants repeatedly as a remedy for various diseases of livestock. For example, Cyphostemma serpens and Viscum congolense were cited by all informants $(100 \%)$ as sources of remedy for foot and mouth disease and shivering and abnormal breathing respectively. Dichrostachys cinerea and Syzygium guineense were also cited by 49 (98\%) informants as sources of remedy for hepatitis and shivering and leech infection respectively (Table 4).

Table 4. Informant Consensus on most frequently used medicinal plants 


\begin{tabular}{|llll|}
\hline Botanical name of medicinal plants & Disease treated & No. of informants & $\%$ \\
\hline Cissus quadrangularis & Black leg & 48 & 96 \\
\hline Cyphostemma serpens & Foot and Mouth Disease & 50 & 100 \\
\hline Dichrostachys cinerea & Hepatitis & 49 & 98 \\
\hline Microglossa pyrifolia & Dermal wound & 48 & 96 \\
\hline Prunus africana & Coughing in cattle & 47 & 98 \\
\hline Syzygium guineense & Leech infection & 49 & 96 \\
\hline Tragia cinerea & Diarrhea & 48 & 100 \\
\hline Viscum congolense & Shivering and abnormal breathing & 50 & \\
\hline
\end{tabular}

\section{Effectiveness of ethnoveterinary medicinal plants}

Six main livestock ailment categories were identified from the total of 79 veterinary diseases reported in the district. The highest Informants' Consensus Factor (ICF) values were recorded for breathing system diseases (0.85), dermatological diseases (0.84), blackleg, hepatitis, and FMD (0.83), and gastro intestinal disease (0.81) categories (Table 5). Hence, the highest plant use citation (55.1\%) was recorded for breathing system diseases.

Table 5. ICF values of traditional medicinal plants used to treat livestock ailments in Suro Barguda District

\begin{tabular}{|llrrrrr|}
\hline No & Disease category & $\begin{array}{c}\text { No. of } \\
\text { species }\end{array}$ & $\begin{array}{r}\text { \% of all } \\
\text { species }\end{array}$ & $\begin{array}{l}\text { Use } \\
\text { citations }\end{array}$ & $\begin{array}{l}\text { \% of use } \\
\text { citations }\end{array}$ & ICF \\
\hline 1 & Breathing system diseases & 17 & 37 & 108 & 55.1 & 0.85 \\
\hline 2 & Gastro - intestinal diseases & 17 & 37 & 86 & 43.9 & 0.81 \\
\hline 3 & 11 & 23.9 & 60 & 30.6 & 0.83 \\
\hline $\begin{array}{l}\text { Black leg, hepatitis and } \\
\text { FMD }\end{array}$ & Dermatological diseases & 9 & 19.6 & 50 & 25.5 & 0.84 \\
\hline 5 & $\begin{array}{l}\text { Muscular - nervous system } \\
\text { diseases }\end{array}$ & 18 & 39.1 & 52 & 26.5 & 0.67 \\
\hline 6 & $\begin{array}{l}\text { Tooth ache, leech infection } \\
\text { and cold }\end{array}$ & 8 & 17.4 & 19 & 9.7 & 0.61 \\
\hline
\end{tabular}

\section{Comparative healing potential of ethnoveterinary medicinal plants}

Cyphostemma serpens revealed the highest fidelity level value (97\%) for blackleg, hepatitis, and FMD disease category, followed by Viscum congolense (96\%) for breathing system diseases. In the 
dermatological therapeutic category, the highest fidelity level value was recorded for Prunus africana (92\%). Ozoroa insignis (87\%) also showed relatively high healing potential under the muscular - nervous system diseases category (Table 6).

Table 6. Fidelity level values of medicinal plants commonly reported against certain livestock ailment category

\begin{tabular}{|lllccc|}
\hline No. & Medicinal plant & Healing category & Np & N & FL value (\%) \\
\hline 1 & Cyphostemma serpens & Black leg, hepatitis and FMD & 22 & 23 & 96.00 \\
\hline 2 & Viscum congolense & Breathing system diseases & 32 & 33 & 97.00 \\
\hline 3 & Prunus africana & Dermatological diseases & 24 & 26 & 92.00 \\
\hline 4 & Ozoroa insignis & Muscular -nervous system diseases & 26 & 30 & 87.00 \\
\hline 5 & Tragia cinerea & Gastro - intestinal diseases & 20 & 24 & 83.00 \\
\hline 6 & Syzygium guineense & Tooth ache, leech infection and cold & 12 & 16 & 75.00 \\
\hline
\end{tabular}

N.B. FL= Fidelity Level, $\mathrm{Np}=$ number of informants who independently cited the importance of a species for treating a particular disease, $\mathrm{N}=$ total number of informants who reported the plant for any given disease.

\section{Use diversity of ethnoveterinary medicinal plants}

All the $\mathbf{4 6}$ medicinal plant species recorded for livestock ailments treatment in the district were cited for one or more uses other than their medicinal role. The proportion of medicinal plant species over different use categories is summarized in Figure 6.

\section{Medicinal use values of selected ethnoveterinary plants}

Traditional medicinal uses of the 46 different medicinal plant species against several livestock ailments were compiled. Of these species, the highest medicinal use values (UVmed) were recorded for Lannea rivae (8.0), Dichrostachys cinerea (7.8), and Ozoroa insignis (6.6) (Table 7).

Table 7. Medicinal use values of selected ethnoveterinary plants 


\begin{tabular}{|lccccc|}
\hline $\begin{array}{l}\text { Medicinal plant } \\
\text { species }\end{array}$ & $\begin{array}{l}\text { No. informants citing the } \\
\text { species }\end{array}$ & $\begin{array}{l}\text { Total } \\
\text { citations }\end{array}$ & $\begin{array}{l}\text { No. of ailments } \\
\text { treated with }\end{array}$ & UVmed. \\
$\begin{array}{l}\text { Cyphostemma } \\
\text { serpens }\end{array}$ & 84 & 504 & 2 & 6.0 \\
\hline $\begin{array}{l}\text { Dichrostachys } \\
\text { cinerea }\end{array}$ & 96 & 749 & 2 & 7.8 \\
\hline Lannea rivae & 118 & 944 & 2 & 8.0 \\
\hline Ozoroa insignis & 102 & 673 & 2 & 6.6 \\
\hline $\begin{array}{l}\text { Solanum } \\
\text { dennekense }\end{array}$ & 68 & 374 & 2 & 5.5 \\
\hline
\end{tabular}

N.B. UVmed = Medicinal use value

\section{Distribution of indigenous knowledge on medicinal plants among different social groups in the community of the study area}

Although more medicinal plants were reported by men (168) than women (28), the difference was not significant $(P>0.05)$ when the average number of medicinal plants mentioned by each group was compared. There was no significant difference seen in the number of medicinal plants listed by informants living around health centers and those living relatively far away from these health centers. However, there was a significant difference $(P<0.05)$ in the number of medicinal plants reported by senior members of the community ( $>40$ years old) and young- to middle-aged members ( $<40$ years old); key informants and randomly taken informants, illiterate and literate informants (Table 8). More number medicinal plants were reported by elders ( $>40$ years old), illiterates, and key informants than by young, literates, and randomly taken informants.

Table 8. Statistical test of significance on the average number of medicinal plants among different informant groups in Suro Barguda District 


\begin{tabular}{|c|c|c|c|c|c|}
\hline Considerations & Informant groups & $\mathbf{N}$ & $\begin{array}{l}\text { Average } \pm \\
\text { SD }\end{array}$ & $\begin{array}{l}\mathrm{t}- \\
\text { value**}\end{array}$ & $\begin{array}{l}p- \\
\text { value }\end{array}$ \\
\hline \multirow[t]{2}{*}{ Gender } & Males & 168 & $2.65^{6.62 \pm}$ & \multirow[t]{2}{*}{1.97} & \multirow[t]{2}{*}{0.97} \\
\hline & Females & 28 & $2.18^{6.05 \pm}$ & & \\
\hline \multirow[t]{2}{*}{ Age } & Youngsters & 110 & $2.07^{5.16 \pm}$ & \multirow[t]{2}{*}{-12.87} & \multirow[t]{2}{*}{$0.00 *$} \\
\hline & Elders & 86 & $2.19^{7.96 \pm}$ & & \\
\hline \multirow[t]{2}{*}{ Literacy } & Illiterates & 146 & $2.31^{7.22 \pm}$ & \multirow[t]{2}{*}{12.92} & \multirow[t]{2}{*}{$0.00 *$} \\
\hline & Literates & 50 & $1.82^{4.28 \pm}$ & & \\
\hline \multirow[t]{2}{*}{$\begin{array}{l}\text { Proximity to the health } \\
\text { center }\end{array}$} & Near to the health center & 11 & $2.37^{6.00 \pm}$ & \multirow[t]{2}{*}{-0.94} & \multirow[t]{2}{*}{0.36} \\
\hline & $\begin{array}{l}\text { Far away from the health } \\
\text { center }\end{array}$ & 185 & $2.57^{6.5 \pm}$ & & \\
\hline \multirow{2}{*}{$\begin{array}{l}\text { Informant } \\
\text { category }\end{array}$} & Key informants & 24 & $\begin{array}{l}10.76 \pm \\
1.09\end{array}$ & \multirow[t]{2}{*}{25.75} & \multirow[t]{2}{*}{$0.00 *$} \\
\hline & $\begin{array}{l}\text { Randomly taken } \\
\text { informants }\end{array}$ & 172 & $2.04^{5.85 \pm}$ & & \\
\hline
\end{tabular}

*Significant difference $(p<0.05)$; $*$ t(0.05) (two tailed), degree of freedom $(d f)=223$,

$\mathrm{N}=$ number of respondents

\section{Discussion, Conclusion, And Recommendation}

\section{Discussion}

\section{Medicinal plant diversity used for ethnoveterinary in Suro Barguda District}

The reported ethnoveterinary medicinal plants of Suro Barguda District showed that the study area is relatively rich in ethnoveterinary medicinal plant diversity and indigenous knowledge related to each traditionally used species (Appendix 1). Comparatively a high diversity of ethnoveterinary medicinal plant species was recorded than in other cultural communities of Ethiopia [34, 35, 36]. All the documented ethnoveterinary plant species were harvested from the wild. This finding was in agreement with the reports of [37] in which $95.7 \%$ of the medicinal plants were collected from the wild. Overgrazing, 
deforestation, charcoal making, and firewood collection were claimed as major factors affecting the ethnoveterinary plant species of the study area.

\section{Specification of livestock ailments, number, and part of plant species used}

Even though livestock traditional medicinal plants of the district were asserted to be applied for ailments affecting chicken, sheep/goats, cattle, equines, or camels the majority of the reported medicinal plant species were found to be applied to treat one or more of the sixty-two different cattle ailments (Appendix 1). Eighteen (39\%) equal medicinal plant species were mentioned to be used specifically against twentyone ailments of goats/sheep and nineteen ailments of equines respectively.

The majority of ethnoveterinary medications were reported to comprise medicinal parts of a single medicinal plant. This finding was in line with the reports of [35, 37, 38, 39, 40]. The remaining was prepared using formulations from two or more species. [34] also reported that healers used multiple plants in the mixture to increase the strength and efficacy of the drug. Amongst all plants reported, the highest proportion of species was claimed to treat breathing problems followed by diarrhea. The highest number of multiple ethnoveterinary uses was recorded for Croton macrostachyus and Teclea salicifolia (each used against six ailment types) while Calpurnia aurea was used to treat five livestock diseases (Appendix 1).

Similar to some other previous findings such as $[34,37,39,40]$ leaves were the most widely used plant parts for ethnoveterinary medicine preparations followed by barks and roots in the study area (Figure 4). On the other hand, other findings for instance [36, 41,42,] reported different results which showed that roots were the most frequently utilized plant parts in their respective research areas. The possible reason could be that people living in different ecological zones could use different plants and plant parts in their treatment system. The majority $(97.8 \%)$ of remedies were prepared from freshly harvested plant parts. This finding was in line with the reports of $[36,39,40,42,43,44,45]$, whereas $2.2 \%$ were prepared from dried forms. As reported by informants, from their long experience high efficacy was attained from freshly collected plant parts since they contain many bio-active ingredients in the form of secondary metabolites.

Viscum congolense, Clematis simensis, and Lannea rivae were the most preferred ethnoveterinary medicinal plants to treat breathing system diseases which were the most prevalent animal health problems reported in the study area (Table 2).

\section{Livestock ailments, remedy preparation, routes of administration and dosages}

Most of the veterinary ailments belong to the breathing system disease category followed by gastrointestinal diseases. Breathing problems and diarrhea were known to be the most commonly described forms of veterinary ailments in the district. This result corroborates with the report of [40]. Healers treat veterinary ailments based on observation of the animals or evidence obtained by asking the livestock owners about major symptoms shown by the diseased animals and medicines were commonly 
given only after the diseased animal was visually examined by a traditional healer for any symptom on its suspected body part.

Diverse modes of ethnoveterinary remedy preparations were mentioned to be used in the district based on the type and degree of complexity of livestock ailment. Chopping/pounding the remedial part and making its solution with cold water was found to be the major method of local remedy preparation (Figure 5). This finding was in agreement with the reports of many studies such as $[44,45,46]$. Oral administration of traditional medicines was reported as the main route in the treatment method of most diseases. This finding was in line with the reports of $[8,36,37,42,44,46]$. This was followed by nasal administration. Rubbing or pasting herbal preparations were also commonly reported treatment methods for handling dermatological diseases. The physical appearance of the diseased animal and visually confirmed the degree of complexity of illness was used to determine doses of traditional medicines in treating livestock ailments. Some traditional practitioners reported the use of the coffee cup, water glasses, and bottles to determine dosage for some traditional medicines, while others reported using their fingertip or full of a small dish unprocessed parts to treat ailments. However, no standardized doses of herbal preparations were reported by traditional healers for any of the preparations used to treat livestock ailments in Suro Barguda District even if they used such various units of measurements. Similar findings have been reported in other studies in Ethiopia such as $[18,44,47,48,49]$.

Since informant consensus is used to identify the most cited plant species for its particular importance the highest plant use citation was recorded in the present study for breathing system diseases with the highest ICF value (Table 5). Viscum congolense was highly effective in treating breathing system diseases, whereas Cyphostemma serpens was identified as having the highest healing potential in treating blackleg, hepatitis, and FMD (Foot and Mouth Diseases) with FL tests (Table 6). Informant consensus factor values (ICF values) were used to identify the harmony of the informants on the reported cure for the group of ailments (breathing system diseases) of the plant while fidelity level (FL) computes the significance of a species (Viscum congolense) to treat a given disease (breathing system diseases). Hence, their analysis values were confirmed as the information obtained was tangible.

\section{Use diversity of ethno veterinary medicinal plants}

With direct matrix ranking exercise made among five ethnoveterinary medicinal plant species to identify those having multipurpose, Prunus africana was ranked first (most - threatened) followed by Syzygium guineense var. guineense and Combretum collinum. Higher direct matrix ranking values indicated that the plants have been used for different purposes and vice versa. The output indicated that these multipurpose medicinal plant species were exploited more for firewood, charcoal, and construction purposes than for their medicinal uses.

All ethnoveterinary medicinal plant species in the district were cited for one or more uses other than their medicinal role such as used for environmental services, construction and material making, fodder, and live fences, fuelwood (charcoal and firewood), as wild food or poison (Figure 6). Out of the 46 different 
medicinal plant species used for livestock ailments treatment, the highest medicinal use values (UVmed) were recorded for Lannea rivae followed by Dichrostachys cinerea (Table 7).

Water served as 'solvent' almost in all ethno formulations of traditional medicines whenever dilution is required. Different additives were incorporated in $23.4 \%$ of the whole ethno formulations. Informants reported that certain additives were frequently used to improve the suitability of some remedies that were taken orally either through reducing their bitterness and bad flavor or increasing their efficacy. The highest usage of additive was reported for "Magado" salt (locally produced salt).

\section{Distribution of indigenous knowledge on medicinal plants among different social groups in the community of the study area}

Though more medicinal plants were reported by men than women, the difference was not significant ( $P$ $>0.05$ ) when the average number of medicinal plants mentioned by each group was compared. This could be because both men and women were knowledgeable on the use of traditional plant remedies regardless of the relative dominance of medicinal plant tradition by men which could be related to the transfer of traditional knowledge along the male line in the study area. Similar results were reported by $[43,50]$. Furthermore, [51] reported as there was relatively equivalent medicinal plant knowledge among men and women traditional medicine practitioners among three communities in northeastern Brazil, and [52] reported similar information for a community in southwest Niger. There was no significant difference observed in the number of medicinal plants listed by informants living around health centers and those living relatively far away from these health centers. However, there was a significant difference $(P=0.00)$ in the number of medicinal plants reported by senior members of the community ( $>39$ years old) and young- to middle-aged members ( $<40$ years old) - more number of medicinal plants was reported by elders than by youngsters. This could be due to their high degree of opportunity for more cultural contact and experience with plants and associated therapeutic uses than that of younger people or due to the absence of sharing indigenous knowledge freely because of its secrecy and if it presents being along the preferred male line of the family of the ethnic group of the study area. Similar reports were made by [34, $44,50,53,54,55,56]$. Similarly, significant differences were also seen in the number of medicinal plants reported by key informants and randomly taken informants, illiterate and literate informants. More medicinal plants were reported by illiterates and key informants than literates and randomly taken informants (Table 8). This could again be related to the impact of lifelong experience and serious secrecy in using medicinal plants in the former, and modernization in the latter case. Similar results were reported by $[54,55]$.

A large number and types of livestock diseases (79 disease types) for which diseased livestock was visited by traditional healers indicated a preference of local people in the study area to use traditional medicines than modern medication. The reported reasons for this to happen were efficacy and availability of these medicines, cultural trend, and life standard (being poor), factors which force the community to visit traditional healthcare practitioners than modern healthcare centers with unreasonable prices. Similar findings were reported by $[42,44]$. 


\section{Indigenous knowledge transfer}

Using wild plants for medicine traditionally is an indigenous science. Indigenous knowledge systems are the multifaceted assortments of knowledge, know-how, practices, and representations that guide human societies in their numerous interactions with the natural environment such as agriculture and animal husbandry; struggles against disease and injury; and strategies for coping with changing environments. It is through this day-to-day and the inevitable interplay between people and surroundings that indigenous knowledge systems have developed miscellaneous structures and content; complication, flexibility, and practicality; and distinctive patterns of interpretation anchored in specific worldviews [57].

Knowledge is produced and transferred through communications within specific social and agroecological contexts. Hence, ethnobiological information and practice within any customs have been reported to vary by factors such as geographical basis, traditions, belief, livelihood, educational background, social status and relations, income class, age, and gender $[58,59,60]$. The flow of knowledge from seniors to children and its enrichment subsequently is directly conveyed through observation, imitation, free flow of information among community members, history telling, and myths [61].

The main system of traditional knowledge transfer on types of medicinal plants, traditional concepts of disease, and ways of diagnosis among traditional healers in Suro Barguda District was through word of mouth (no written documents obtained), with maximum secrecy following mainly the selected male line of the family. The way they are sharing their indigenous knowledge with their descendants was also found to be similar. This may cause indigenous knowledge to be threatened shortly unless certain measures are taken which was also clearly seen in other parts of the country and abroad [34, 44, 50,53, $54,55,56]$.

Traditional knowledge is built with years of experience so elders were more knowledgeable in traditional medicines than youngsters in the study area. The depth and width of traditional knowledge on medicinal plants become lesser and lesser due to its secrecy, the unwillingness of the young generation to gain the knowledge, influence of modern education which all result in its gradual disappearance. Ethnomedicinal knowledge diminishes with the death of elderly knowledgeable members of the society since fewer and fewer young people are willing to acquire this knowledge. That is why [62] said that erosion of knowledge on medicinal plants is more significant in species collected from forests for use in treating rare and unusual ailments. This finding was in line with the reports of $[63,64,65]$.

\section{Conservation practices}

Dwellers of Suro Barguda District and their livestock population depend mainly on the natural resources of the area for their existence. Deforestation for timber production or construction, overgrazing, charcoal production, and fuelwood collection was claimed to be the anthropogenic causes of resource depletion. This finding was in line with the reports of $[46,66]$. Highly affected dry evergreen montane forest and the remaining woodland area were severely degraded due to overgrazing with immense livestock population 
and illegal charcoal production and fuelwood collection. Not only medicinal plant species were affected but also the vegetation as a whole was in a critical condition. Some conservation practices were implemented in a very specific area of the district but this did not guarantee the wellbeing of plant diversity and their contribution to the perpetuation of life in the area (no pronounced conservation effort).

Inhabitants of the study area simply went to the forest, woodland, or grazing area to collect medicinal plants as their need arose and did not worry about the long-term survival of these plants. Most of these informants gave the reason that the medicinal plants were easily accessible in their surroundings and hence no need for personal effort to conserve these plants. Because of this many plants in the study area were highly threatened with anthropogenic and natural factors. The natural factor affecting medicinal plant species was irregular and very short rainy season, prolonged and recurrent drought. Hence, sustainable land management which involves both the conservation and improvement of the present vegetation cover, such as through enrichment planting, enhancing soil fertility, and rehabilitating degraded lands is required to reduce pressure on and destructive use of the natural resources. This could be achieved by solving the problems associated with open access to forest resources through sustainable forest management involving the local communities neighboring this vegetation as comanagers and co-beneficiaries of the generated revenues.

\section{Conclusion}

Most of the ethnoveterinary medicinal plants of the study area were found to play a multipurpose role across different use categories and consequently, some are under serious pressure challenging their survival. Hence, recorded high use value indices of multipurpose plant species in the study area can be used as signals of high use pressure and can be used as keys to design and implement well-coordinated complementary in situ and ex situ conservation activity to save these widely used plant species. These findings were in agreement with the third hypothesis of the research "the local people are equipped with unique indigenous knowledge and culture in using ethnoveterinary medicinal plants for different purposes." Findings of this study indicated that there was higher usage of leaves of most medicinal plants to prepare various traditional remedies. Even though collecting these parts seems not harming much the regular physiological activities of the plant, those plants only with a limited number of leaves can be endangered unless proper consideration is given. Hence, conservation work in the area needs to give prior attention to protect such types of plant species. Traditional practitioners diagnose their diseased livestock through observation and asking the owner of the animal about the signs of the disease and then prepare the medicine to administer it accordingly based on their cultural knowledge on symptoms, corresponding illnesses, and therapeutic medicinal species held in the knowledge of indigenous people. This may be more effective if these people obtain certain training from modern health professionals about how to identify some diseases based on their symptoms especially those which are easily communicable to minimize the possible severe problems that could happen on the local livestock and how to determine the doses of the preparations. 
Traditional practitioners in the district also showed varying degrees of traditional medicinal plant use knowledge based on differences in age, experience, gender, and education level. More ethnomedicinal knowledge was observed in elderly members of the community than in younger groups; experienced/key practitioners than the general public; and more with the illiterate than the literate. Because of the cultural norm and secrecy of the traditional medication system, this knowledge is transmitted along the selected male line of the family members due to which males could be more knowledgeable than females even if the difference in knowledge concerning gender was not exaggerated in the study area. Oral transmission of traditional knowledge and its flow only through the selected male line of the family for its secrecy may cause it to be depleted shortly concerning modernization and ignorance of the new generation. High ICF, FL, and medicinal use values testing exercises result showed that the selected medicinal plants of Suro Barguda District have promising bioactivity elements. These findings were in line with the fourth hypothesis "the traditional herbalists in the community are knowledgeable about healing plants, their preparation, and applications."

\section{Recommendations}

Plants afford a great economic and social value for the rural communities living as semi- pastoralists being used as forage and medicine for their livestock, source of both timber and other non-timber products as well as regulators of climatic conditions. Therefore, to ease the present human influence on the natural vegetation and for its future management on a sustainable basis in the district, the following recommendations are forwarded:

- Raising public awareness, through extension programs, on the multiple uses of plant resources to safeguard the plant diversity;

- Conservation action should be followed with close follow up about its sustainability not to be affected by resources used for different needs;

- In natural resource conservation such as regional or national protected areas, giving responsibility and sense of ownership to the local community so that they assume it as their property and they will manage and conserve it to become beneficiaries of the economic payback that can be obtained from this action;

- Conservationists should set up medicinal plant nursery sites in co-operation with the District's Agriculture and Rural Development Office to propagate seedlings of the most-preferred medicinal plants, followed by a parallel distribution of seedlings to the local community as a possible means of reducing pressure on natural stands and conserve useful medicinal plant species;

- The indigenous knowledge of pastoralists about plants (a traditional system of rangeland management) and livestock (breeding different species of livestock (grazers with browsers), as well as their environmental management system (traditional forest, soil and water conservation system), should be incorporated in the planning and implementation of developmental interventions;

- Carefully designed community-based and participatory approaches are recommended to control bush encroachment through minimizing deforestation, overgrazing, and raising awareness of the 
local community to use controlled burning by clearing unwanted bushes;

- Medicinal plants such as Prunus africana and Syzygium guineens should be given conservation priority for their multipurpose uses;

- Conservation measures which might be designed for vegetation resources of Suro Barguda District by policymakers, natural resource managers or stakeholders would need to take into account special protection and monitoring of the endemic taxa as well as the most important useful plant species found in the vegetation;

- Good effort should be made by stakeholders to close the observed generation gap in indigenous knowledge (b/n elders and youngsters) through uninterrupted professional support and training of local communities to preserve their traditional knowledge and practices through systematic documentation;

- The efficacy of the preparations, techniques, and practices need to be investigated to identify promising plants for use in livestock development plans. So, bioactive chemicals of Croton macrostachyus and Teclea salicifolia should be screened out in scientific works for their pharmacological potentials because they were used to treat different livestock diseases (about six diseases each).

\section{Declarations}

\section{Supplementary information}

The online version contains supplementary material available at https://doi. org/10.1186/s13002-2100078

Additional file: Summary of medicinal plants used to treat livestock ailments in Suro Barguda District; Key: $(\mathrm{Hb}=$ Habit, $\mathrm{Pu}=$ Parts used, $\mathrm{Ut}=\mathrm{Used}$ to treat, $\mathrm{Cp}=$ Condition of preparation, Ra= Route of application, $\mathrm{T}=$ Tree, $\mathrm{H}=$ Herb, Sh=Shrub, $\mathrm{Cl}=$ Climber, Ls=Livestock, $\mathrm{F}=$ Fresh, $\mathrm{D}=$ Dried, F/D=Fresh/Dried, O=Oral, Dm=Dermal, Na=Nasal, Op=Optical, Er=Ear, L=Leaf, Rt=Root, St=Stem, Ba=Bark, Fl=Flower, Fr=Fruit, $\mathrm{S}=$ Seed, Bu=Bulb, Rh= Rhizome, La=Latex, Ds=Distribution, $\mathrm{C}=$ Common, R=Rare, *=Endemic).

\section{Acknowledgement}

We would like to thank Bule Hora University; Governmental Officials, societal leaders, and the local community of Suro Barguda District for their full cooperation in adjusting favorable conditions for gathering the data and effectiveness of this original research.

\section{Authors' contributions}

Dr. Mersha Ashagre Eshete carried out fieldwork, collected and analyzed the data, and wrote the manuscript. Dr. Ermias Lulekal Molla critically reviewed and improved the first draft of the manuscript. The two authors have read and approved the final version of the manuscript. 


\section{Funding}

As one of the three main tasks of all university instructors (Teaching, providing community service, and carrying out research), this research was funded by Bule Hora University Research and Community Service V/P Office to glean out indigenous knowledge of the local community and disclose it for the whole world through publishing the research output on the reputable journal, of which this publisher is the one.

\section{Ethics approval and consent to participate}

These Traditional medicinal plants used to treat livestock with their accompanying indigenous knowledge study was approved by the concerned bodies of Bule Hora University. During our field investigations, all stakeholders in this study, including users of ethnoveterinary medicines, the local community of Suro Barguda District, and all authors willingly agreed to participate in the study, use the data related to their knowledge and publish the results.

\section{Consent for publication}

Consent for publication has been obtained from the Scientific Research Committee of the Bule Hora University, College of Natural and Computational Sciences, authors, and all stakeholders who participated in this study.

\section{Competing interests}

The authors declare that they have no competing interests.

\section{References}

1. Food and Agriculture Organization of the United Nations. The future of livestock in Ethiopia; Opportunities and Challenges in the face of uncertainty, 2019.

2. Dinesh, K. Ethno-veterinary practices: A boon for improving indigenous cattle productivity in Gaushalas Livestock Research for Rural Development. National Bureau of Animal Genetic Resources Haryana (India), 2007, 19.

3. Jarakabande K. Ethno veterinary medical traditions and methodology's for their documentation, assessment and promotions. Foundation for Revitalization of Local Health Traditions (FRLHT), Bangalore - India, 2002.

4. McCorkle, C. Back to the future lessons from ethnoveterinary research, development extension for studying and applying knowledge. Journal of the Agricultural, Food and Human, 1995.

5. 5. Traditional Medicines Strategy 2002-2005. World Health Organization, Geneva WHO, 2002.

6. Mekonnen Bishaw. Attitudes of modern and traditional medical practitioners toward cooperation. Ethiop. Med J. 1990, 28:63-72. 
7. Thomas, E. Quantitative Ethnobotanical Research on Knowledge and Use of Plants for Livelihood among Quechua, Yuracare, and Trinitario Communities in the Andes and Amazon Regions of Bolivia. PhD thesis, Ghent University, 2008.

8. Sori, T, Bekana, M., Adugna, G. and Kelbessa, E. Medicinal Plants in the ethno veterinary practices of Borana pastoralists, Southern Ethiopia. International Journal. Appl Res Vet Med. 2004; 2: 220-225.

9. Ngeh, J., Nuwanyakpa, M. and Djang, S. Ethno veterinary medicine, a practical approach to the treatment of cattle diseases in sub-Saharan Africa, Agromisa Foundation and CTA, Wageningen. Nigeria. Research Journal of Agricultural and Environmental Management. 2007; 1: 25-33.

10. McCorkle C. An introduction to ethnoveterinary research and development. Journal of Ethnobiology. 1998; 6: 129-149.

11. Mathias, E. and McCorkle, C. Ethno veterinary Medicine: An Annotated Bibliography of Community Animal Healthcare, ITDG, London, UK.2004.

12. Tabuti, J., Dhillion, S. and Lye, K. Ethno veterinary medicines for cattle (Bos indicus) in Bulamogi County, Uganda: plant species and mode of use. Journal of Ethnopharmacology, 2003; 88: 279- 286.

13. Mahima, Rahel, A., Deb, R., and Latheef, S. Immmuno modulary and therapeutic potential of herbal, traditional/indigenous and ethno veterinary medicine. Pakistan journal of biological sciences. 2012; 15.

14. Kubkomawa, H., Nafarnda, D., Adamu, S., Tizhe, M., and Daniel, T., et al. Review Ethno-veterinary health management practices amongst livestock producers in Africa. Faculty of Veterinary Medicine University of Abuja, Nigeria. Journal of Agricultural Sciences. 2013; 1: 252-257.

15. Bekele A. and Musa A. Ethnoveterinary practice in Chiro District, western Hararge, Ethiopia. Pharmacologyon line. 2009; 1: 128- 139.

16. Mesfine $T$, and Mekonnen $L$. The role of traditional veterinary herbal medicine and its constraints in the animal health care system in Ethiopia. In: Conservation and Sustainable Use of Medicinal Plants in Ethiopia. Medhin Zewdu and Abebe Demissie (Eds); Institute of Biodiversity Conservation and Research, Addis Ababa, Ethiopia, 2001; 22-28.

17. Fekadu Fullas. Ethiopian Medicinal Plants in Veterinary Healthcare A Mini-Review; 2010.

18. Tafesse Mesfin and Mekonen Lemma. The role of traditional veterinary herbal medicine and its constraints in animal health care system in Ethiopia, 2001. In: (Medhin Zewdu and Abebe Demissie eds.). Proceeding of the National Workshop on Biodiverssity Consevation and Sustainable use of medicinal plants in Ethiopia, 28 April- o1 May 1998, pp 23-33. IBCR, Addis Ababa.

19. Yibrah T. Study on Ethnoveterinary practices in Amaro Special district southern Ethiopia. European Journal of Pharmaceutical and Medical Research, 2015.

20. Tessema Tanto, Mirutse Giday, Negusu Aklilu, and Teshome Hunduma. Medicinal Plants Biodiversity. National Biodiversity Strategy and Action Plan (NBSAP) Project. Institute of Biodiversity Conservation and Research (IBCR), Addis Ababa, Ethiopia, 2003.

21. Lulekal, E., Kelbessa, E., Bekele, T. and Yineger, H. An ethnobotanical study of medicinal plants in Mana Angetu District, southeastern Ethiopia. J. Ethnobiol. Ethnomed, 2008; 4: 1-10. 
22. Giday, M., Asfaw, Z. and Woldu, Z. Medicinal plants of the Meinit ethnic group of Ethiopia: An ethnobotanical study. J. Ethnopharmacol., 2009; 124: 513-521.

23. Befikadu Esayas, Belay Simane, Ermias Teferi, Victor Ongoma, and Nigussie Tefera. Climate Variability and Farmers' Perception in Southern Ethiopia; Advances in Meteorology, 2019; Article ID 7341465.

24. Mekonnen Adnew Degefu and Woldeamlak Bewket. Variability and trends in rainfall amount and extreme event indices in the Omo-Ghibe River Basin, Ethiopia; Springer-Verlag Berlin Heidelberg, 2013.

25. Friis et al. Atlas of the Potential Vegetation of Ethiopia. Addis Ababa: Addis Ababa University Press and Shama Books, 2011.

26. Heinrich, M., Ankli, A., Frei, B., Weimann, C. and Sticher, O. Medicinal plants in Mexico: Healers' consensus and cultural importance. Social Science and Medicine, 1998; 47:1859-1871.

27. Cotton, C. Ethnobotany: Principles and Applications. John Wiley and Sons, New York, 1996.

28. Cunningham, A. African medicinal plants, setting priorities at the interface between conservation and primary healthcare. People and plants working paper 1; 1993, Paris, France: UNESCO.

29. Martin, G. Ethnobotany: A method Manual. Chapman and Hall, London, 1995.

30. Hoffman, B. and Gallaher, T. Important indices in ethnobotany. Ethnobot Res Appl. 2007; 5:201-18.

31. Höft, M., Barik, S. and Lykke, A. Quantitative ethnobotany. Applications of multivariate and statistical analysis in ethnobotany. Peoples and plants working paper 6. UNESCO. Paris, France, 1999.

32. Heinrich M. Ethnobotany and its role in drug development. Phyother Res. 2000; 14:479-88.

33. Alexiades, M. Collecting Ethnobotanical Data. An Introduction to Basic Concepts and Techniques. In: Selected guidelines for Ethnobotanical Research: A Field Manual, Alexiades, M. N. and Sheldon, J. W. (eds.), 1996. The New York Botanical Garden, Bronx, New York, pp. 53-94.

34. Haile Yineger, Delenasaw Yewhalaw, and Demel Teketay. Ethnomedicinal plant knowledge and practice of the Oromo ethnic group in southwestern Ethiopia. Journal of Ethnobiology and Ethnomedicine, 2008a; 4:11.

35. Mirutse Giday; Zemede Asfaw, and Zerihun Woldu. Ethnomedicinal study of plants used in Sheko ethnic group of Ethiopia. Journal of Ethnopharmacology, 2010; 132:75-85.

36. Ermias Lulekal, Zemede Asfaw, Ensermu Kelbessa, and van Damme, P. Ethnoveterinary plants of Ankober District, North Shewa Zone, Amhara Region, Ethiopia. J. Ethnobiol. Ethnomed, 2014; 4: 10.

37. Mirutse Giday, Zemede Asfaw, Thomas Elmqvist, and Zerihun Woldu. An ethnobotanical study of medicinal plants used by the Zay people in Ethiopia. Journal of Ethnopharmacology, 2003; 85: 4352.

38. Debela Hunde, Zemede Asfaw, and Ensermu Kelbessa. Use of traditional medicinal plants by people of 'Boosat' sub district, Central Eastern Ethiopia. Ethiopian Journal of Health Sciences, 2006; 16(2):141-155.

39. Getu Alemayehu, Zemede Asfaw, and Ensermu Kelbessa. Ethnobotanical study of medicinal plants used by local communities of Minjar-Shenkora District, North Shewa Zone of Amhara Region, 
Ethiopia. Journal of Medicinal Plants Studies, 2015; 3(6): 01-11.

40. Mersha Ashagre, Ensermu Kelbessa, and Gemedo Dalle. Ethnobotanical study of medicinal plants in Guji Agro-pastoralists, Bule Hora District of Borana Zone, Oromia Region, Ethiopia. Journal of Medicinal Plants Studies, 2016; 4(2): 170-184.

41. Dawit Abebe and Ahadu Ayehu. Medicinal plants and Enigmatic Health practices of Northern Ethiopia, BPE, Addis Ababa, 1993.

42. Fisseha Mesfin, Sebsebe Demissew, and Tilahun Tekelaymanot. An Ethnobotanical study of medicinal plants in Wonago Woreda, SNNPR, Ethiopia. Journal of Ethnobiology and Ethnomedicine, 2009; 5:28.

43. Turner, N. Ethnobotany: Future direction for the new millennium. Manitoba Anthropology Student's Journal, 2000; 16:15 - 18.

44. Ermias Lulekal, Ensermu Kelbessa, Tamrat Bekele, and Haile Yineger. An ethnobotanical study of medicinal plants in Mana Angetu District, southeastern Ethiopia. Journal of Ethnobiology and Ethnomedicine, 2008a; 4:10.

45. Seyoum Getaneh and Zerihun Girma. An ethnobotanical study of medicinal plants in Debre Libanos Wereda, Central Ethiopia. African Journal of Plant Science, 2014; Vol. 8(7), pp. 366 - 379.

46. Solomon Araya, Balcha Abera, and Mirutse Giday . Study of plants traditionally used in public and animal health management in Seharti Samre District, Southern Tigray, Ethiopia. Journal of Ethnobiology and Ethnomedicine, 2015; 11:22.

47. Anteneh Belayneh, Zemede Asfaw, Sebsebe Demissew, and Negussie Bussa. Medicinal plants potential and use by pastoral and agro-pastoral communities in Erer Valley of Babile Wereda, Eastern Ethiopia. Journal of Ethnobiology and Ethnomedicine, 2012; 8:42.

48. Getaneh Gebeyehu, Zemede Asfaw, Abiyu Enyew, and Nagappan, R. Ethnobotanical study of traditional medicinal plants and their conservation status in Mecha Wereda, West Gojjam zone of Ethiopia; Int. J. Pharm.and H. Care Res. 2014; Vol. - 02(03), 137 - 154.

49. Alemayehu Kefalew, Zemede Asfaw, and Ensermu Kelbessa. Ethnobotany of medicinal plants in Ada'a District, East Shewa Zone of Oromia Regional State, Ethiopia. Journal of Ethnobiology and Ethnomedicine, 2015; 11:25.

50. Begossi, A., Hanazaki, N. and Tamashiro, J. Medicinal plants in the Atlantic Forest (Brazil): knowledge, use and conservation. Hum Ecol., 2002; 30:281-299.

51. Almeida, C., Ramos, M., Amorim, E., and Albuquerque, U. A comparison of knowledge about medicinal plants for three rural communities in the semiarid region of northeast of Brazil. J. Ethnopharmacol, 2010; 127:674-684.

52. Ayantunde, A., Briejer, M., Hiernaux, P., Udo, H., and Tabo, R. Botanical knowledge and its differentiation by age, gender and ethnicity in southwestern Níger. J Hum Ecol, 2008; 36:881-889.

53. Uniyal, S., Singh, K., Jamwal, P., and Lal, B. Traditional use of medicinal plants among the tribal communities Chhota Bhangal, Western Himalaya. J. Ethnobiol Ethnomed, 2006, 2:14. 
54. Mirutse Giday, Zemede Asfaw, Zerihun Woldu, and Tilahun Teklehaymanot. Medicinal plant knowledge of the Bench Ethnic group of Ethiopia: an ethnobotanical investigation. J Ethnobiol Ethnomed, 2009, 5:34.

55. Tilahun Teklehaymanot. Ethnobotanical study of knowledge and medicinal plants use by people in Dek Island in Ethiopia. J Ethnopharmacology, 2009, 124:69-78.

56. Slikkerveer, L. Plural Medical Systems in the Horn of Africa: The Legacy of "Sheik" Hippocrates. Kegan-Paul International, London, \& New York, 1990.

57. Nakashima, D. and Rou'e, M. Indigenous Knowledge, Peoples and Sustainable Practice; In: Encyclopedia of Global Environmental Change, Social and economic dimensions of global environmental change, 2002, Volume 5, pp 314-324.

58. Pfeiffer, J. and Butz, R. Assessing cultural and ecological variation in ethnobiological research: The importance of gender. Journal of Ethnobiology, 2005, 25(2):240-278.

59. Ketema Tolossa, Etana Debela, Spiridoula, A., Adugna Tolera, Gebeyehu Ganga, and Houdijk, J. Ethno-medicinal study of plants used for treatment of human and livestock ailments by traditional healers in South Omo, Southern Ethiopia. Journal of Ethnobiology and Ethnomedicine, 2013, 9:32.

60. Phillips, O. and Gentry, A. The useful plants of Tambopata, Peru: I. Statistical hypotheses tests with a new quantitative technique. Economic Botany, 1993, 47:15-32.

61. Firaol Tamiru, Waktole Terfa, Ejigu Kebede, Gizaw Dabessa, Rajeeb Kumar Roy, and Mekonnen Sorsa. Ethnoknowledge of plants used in veterinary practices in Dabo Hana District, West Ethiopia. Journal of Medicinal Plant Research, 2013, Vol. 7(40), pp. 2960-2971.

62. Caniago, I. and Siebert, S. Medicinal plant ecology, knowledge and conservation in Kalimantan, Indonesia. Economic Botany, 1998, 52, 229-250.

63. Firaol Tamiru, Waktole Terfa, Ejigu Kebede, Gizaw Dabessa, Rajeeb Kumar Roy, and Mekonnen Sorsa. Ethnoknowledge of plants used in veterinary practices in Dabo Hana District, West Ethiopia. Journal of Medicinal Plant Research, 2013, Vol. 7(40), pp. 2960-2971.

64. Gebremedhin Gebrezgabiher, Shewit Kalayou, and Samson Sahle. An ethno-veterinary survey of medicinal plants in woredas of Tigray region, Northern Ethiopia. International Journal of Biodiversity and Conservation, 2013, Vol. 5(2), pp. 89-97.

65. Hassan, H., Murad, W., Tariq, A., and Ahmad, A. Ethnoveterinary study of medicinal plants in Malakand Valley, District Dir (Lower), Khyber Pakhtunkhwa, Pakistan. Ir. Vet. J., 2014, 67: 6.

66. Mirutse Giday, Tilahun Teklehaymanot, Abebe Animut, and Yalemtsehay Mekonnen. Medicinal plants of the Shinasha, Agew-awi, and Amhara peoples in northwest Ethiopia. Journal of Ethnopharmacology, 2007, 110 (2007) 516-525.

\section{Figures}




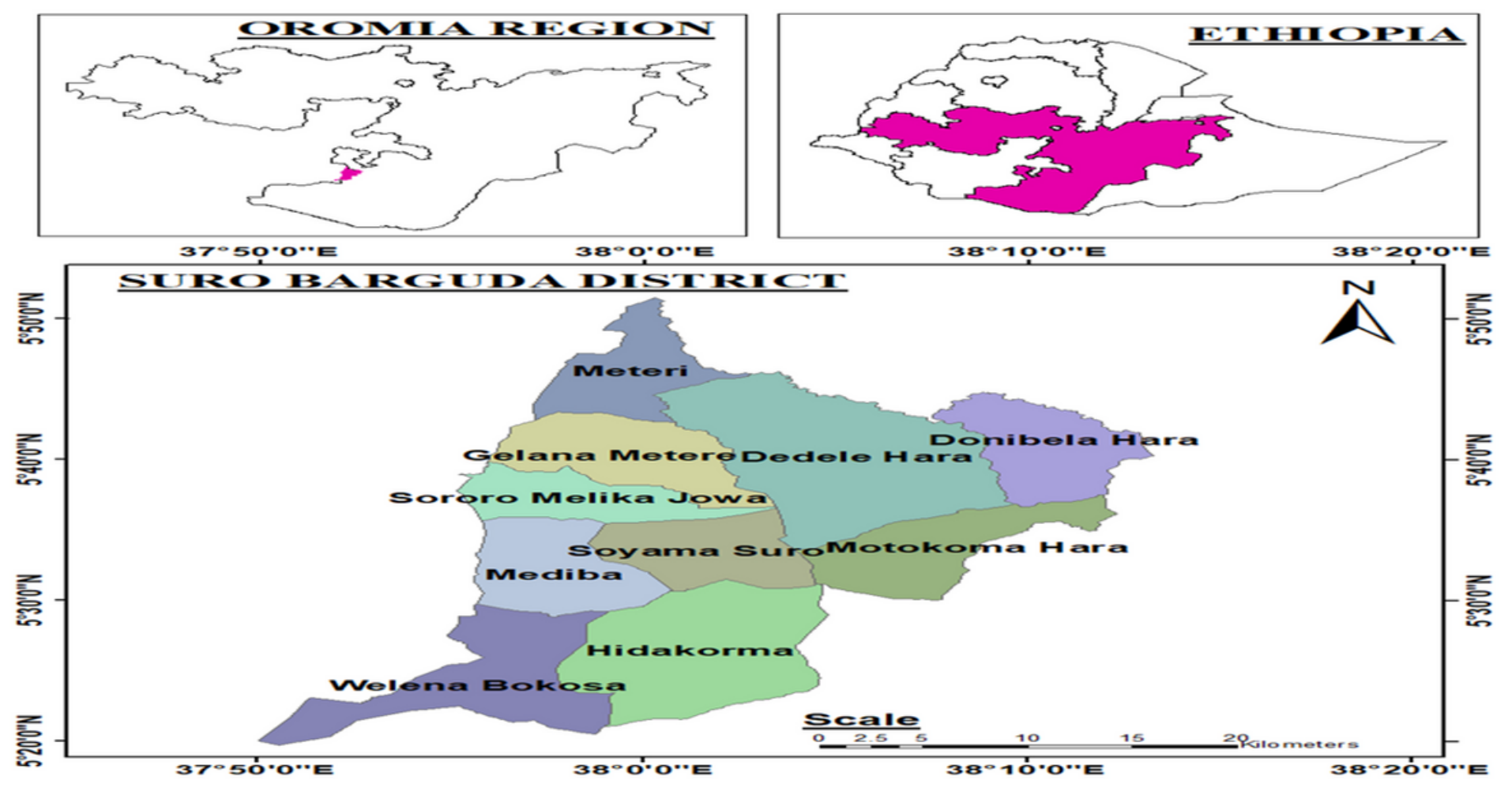

Figure 1

Map of Ethiopia showing Suro Barguda District (the study area) 
Bule Hora (1984 m a.s. 1.)

(2004-2018)

$19.8 \mathrm{c}^{\mathrm{o}} \quad 853 \mathrm{~mm}$

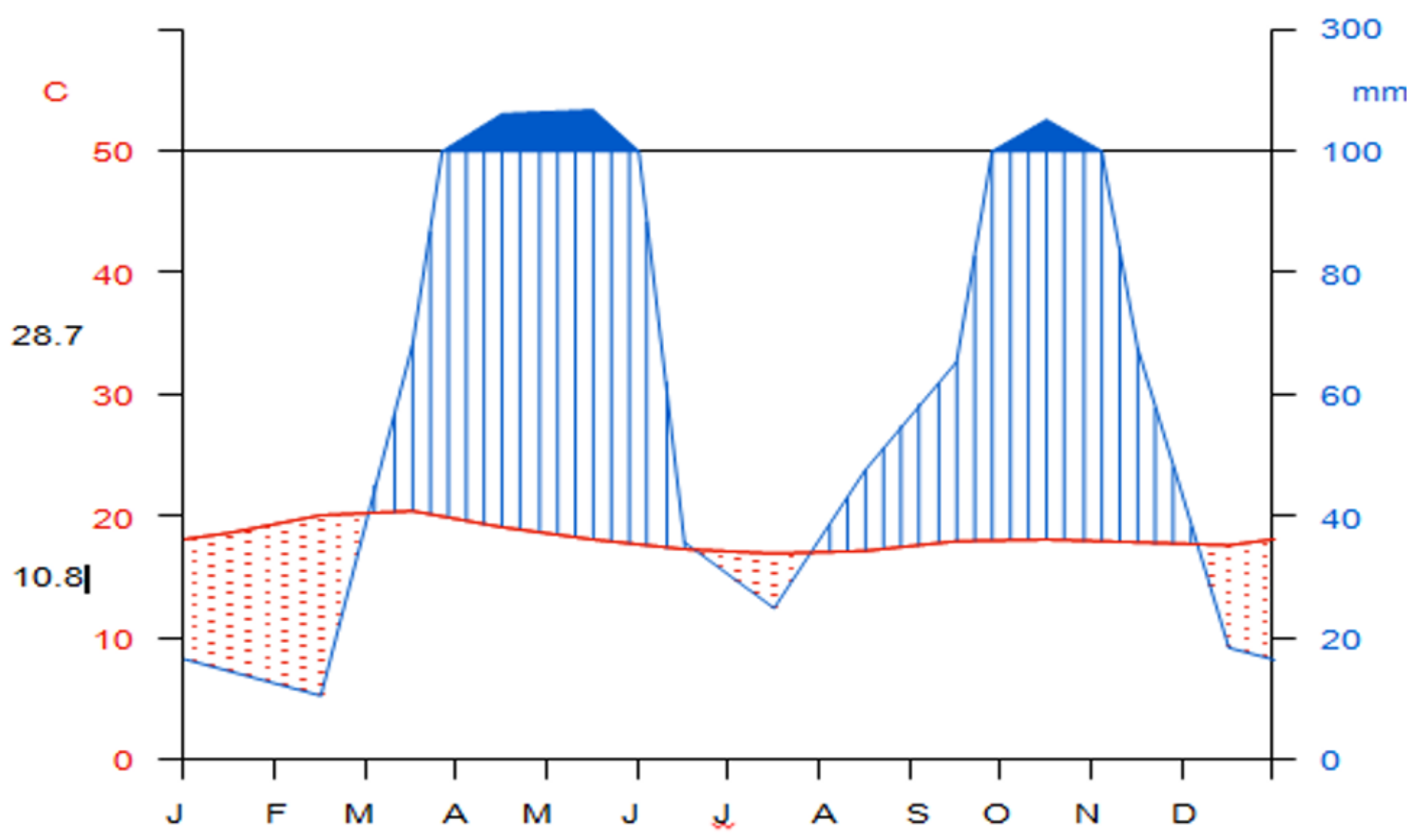

Figure 2

Climadiagram of Bule Hora Station (2004 - 2018) 


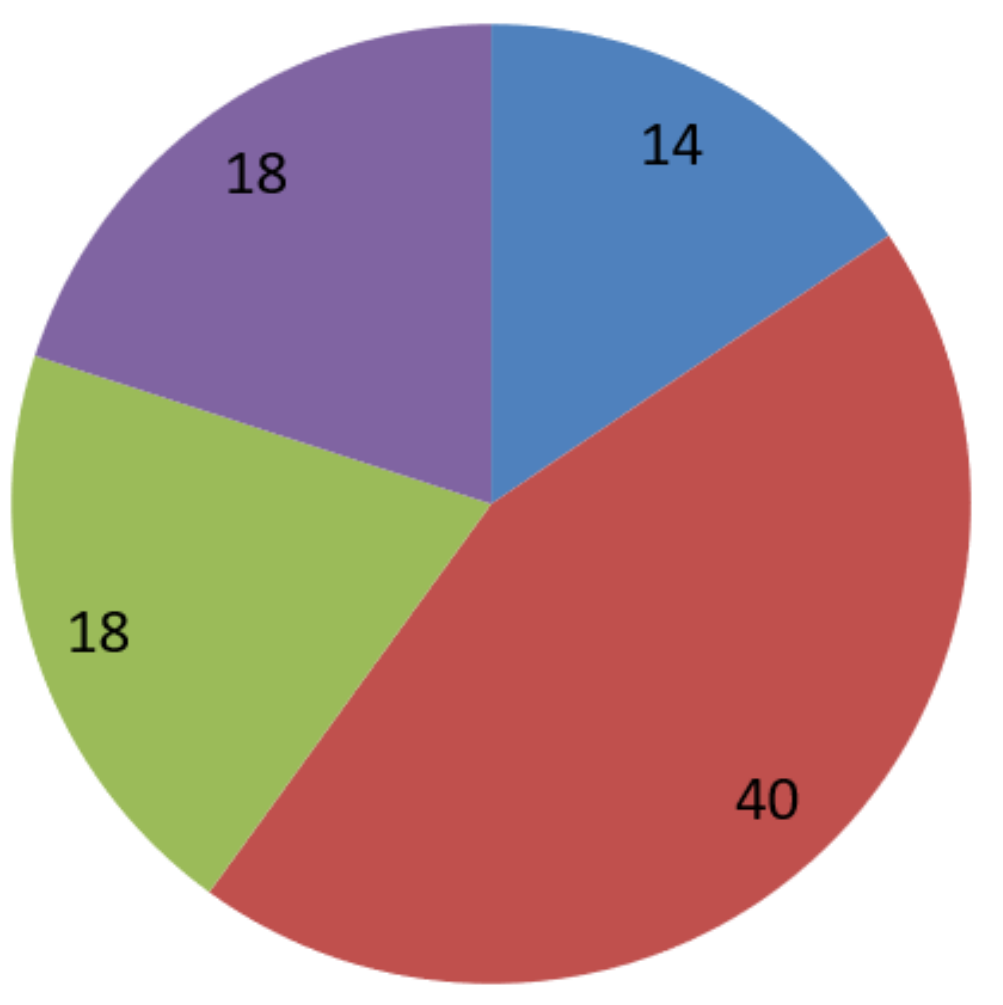

- Camel

- Cattle

Equines

Goats and Sheep

\section{Figure 3}

Number of ethno veterinary plant species used for different livestock types in Suro Barguda District 


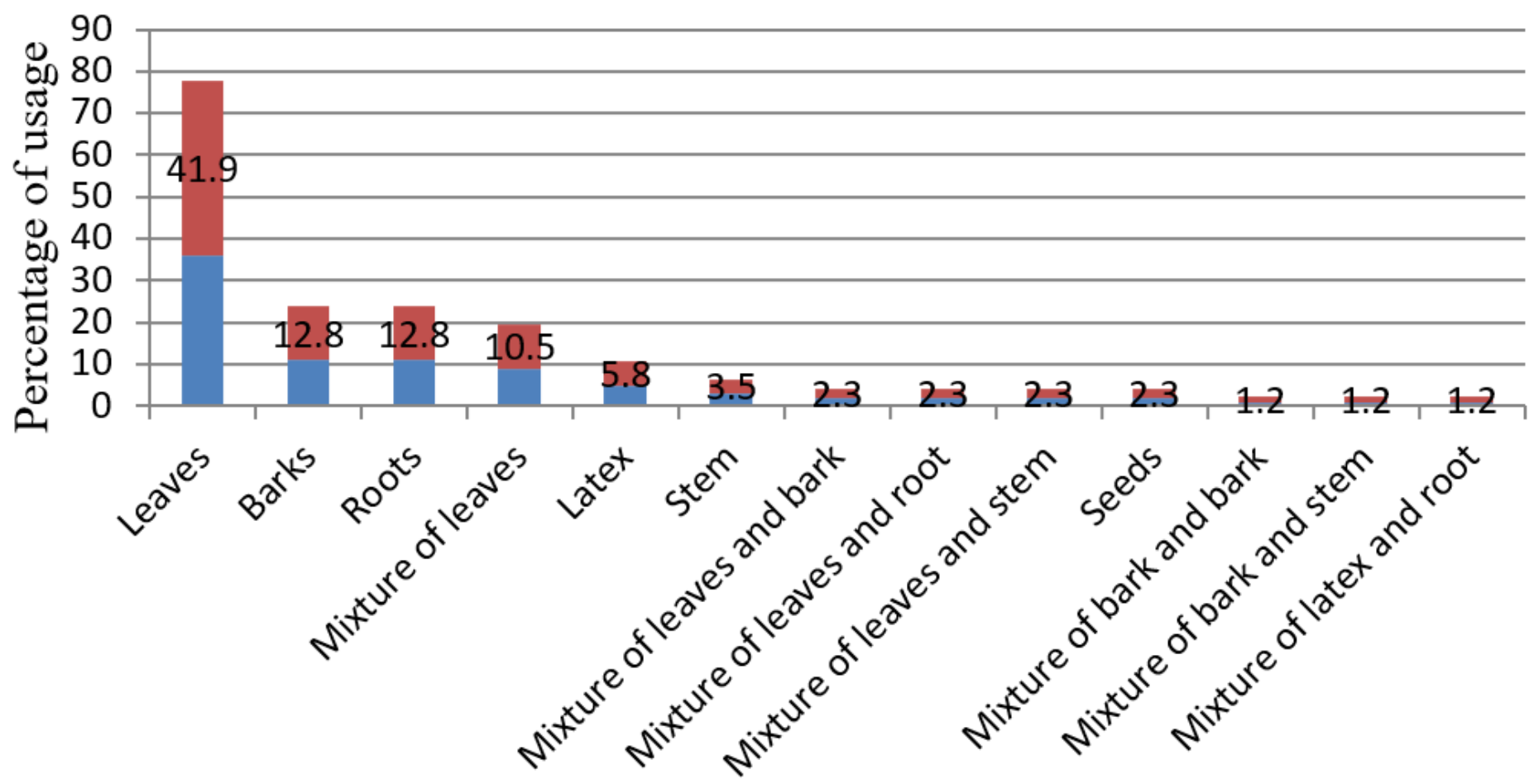

Plant parts used to prepare ethnomedicines

\section{Figure 4}

Plant parts used for ethnoveterinary remedy preparation in Suro Barguda District

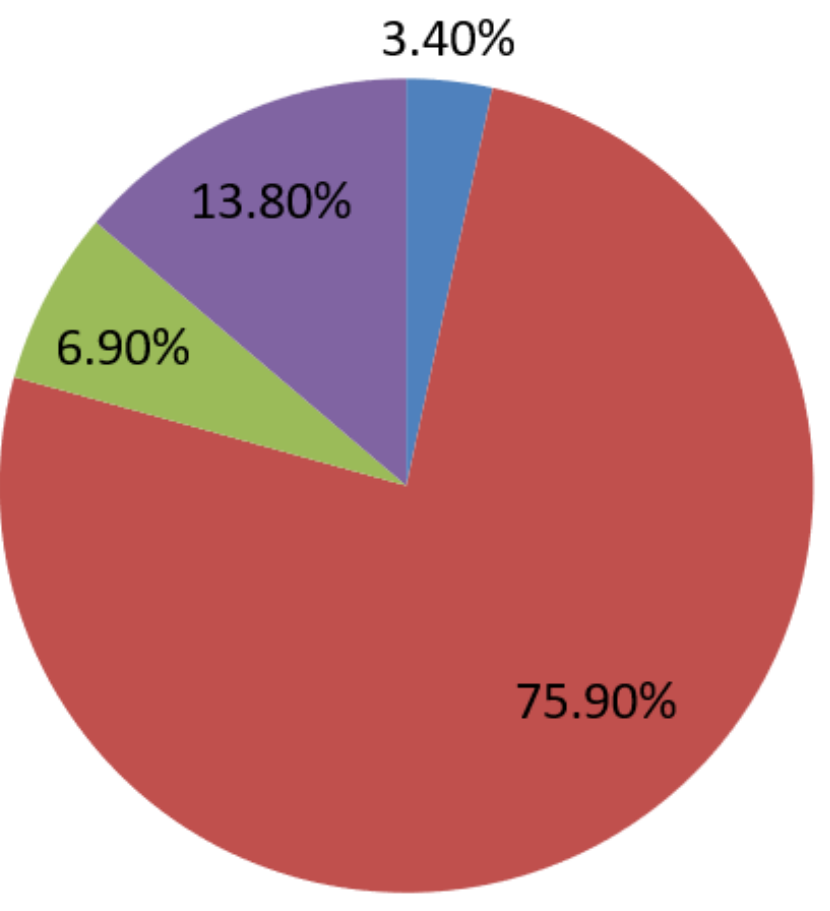

Boiling, cooling and administring

Chopping, homogenizing with cold water and applying

Giving unprocessed plant parts

Pounding/modifying and applying on the infected part 
Forms of remedy preparation and administration for treating livestock ailments in Suro Barguda District

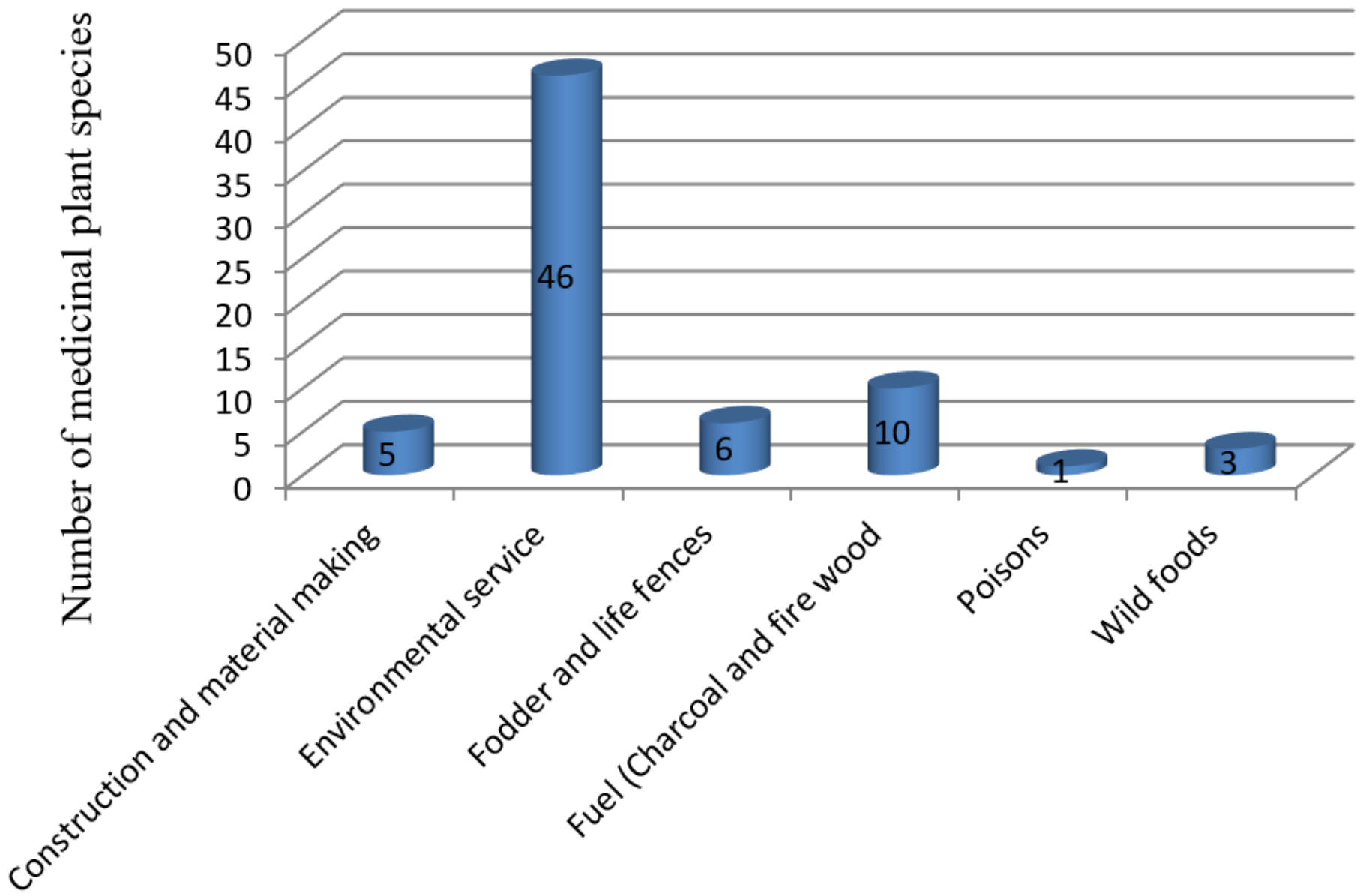

Use categories

Figure 6

Proportion of livestock medicinal plants in Suro Barguda District over different use categories

\section{Supplementary Files}

This is a list of supplementary files associated with this preprint. Click to download.

- AdditionalfileofEthnoveterinarymedicine.docx 